\title{
A REVISION OF THE GENUS ARAUCARIOXYLON OF KRAUS, WITH COMPILED DESCRIPTIONS AND PARTIAL SYNONYMY OF THE SPECIES.
}

\author{
BY \\ F. H. Knowlton, \\ Assistant Curator of the Department of Fossil Plants.
}

Having recently had occasion to identify several species of fossil wood showing the Araucaria like structure from the Potomac formation of Virginia,* the Jurassic of Arizona and New Mexico, $\dagger$ and the Devonian of New York, considerable difficulty was experienced in readily referring to the published descriptious and figures. As a matter of personal convenience a card index was prepared, containing references to the principal descriptions and illustrations. The preparation of this index suggested the idea that other workers in the same field must have experienced similar needs, and this has led to its expansion into the following partial revision and description of the accepted species.

The literature of the subject may be said to date from the publication of Witham's work on the "Internal Structure of Fossil Vegetables," which appeared in 1832. From that time until the present more than fifty species have been established, the descriptions and figures of which are scattered through varions foreign periodicals, or occur in the systematic works of Dawson, Göppert, Unger, Kraus, Felix, and others. From these sources the principal syuonymy has been compiled, together with the description of the species.

The first systematic enumeration of species was that giren by Endlicher in 1847 in his "Synopsis Coniferarum." He there describes fourteen species that have since been referred to the Araucarian type. Unger, in his "Genera et Species Plantarum Fossilium," published in 1850 , enumerates about the same number of species. The most extensive compilation is that given by Kraus in Schimper's "Traité de Paléontologie Végétale," Vol. II, published in 1870-'72. He here established the genus Araucarioxylon, and gives a list of thirty-two species derived from the older genera Araucarites, Dadoxylon, Pissadendron, etc. None of these species are accompanied by descriptions, and the

* Bull. U. S. Geol. Survey, No. 56, p. 50, Pl. viI, figs. 2-5.

† Proc. U. S. Nat. Mns., 1888, pp. 1-4, Pl. I. 
synonymy is also in some cases wrong. The following paper embraces fifty species, the additional ones having been mostly detected since the publication of Kraus's paper, although a few are evident omissions from it.

As above mentioned, it was originally intended to present in this paper only the descriptions and principal references of the well-known forms, and bring it as nearly as possible up to date, by including the species that had been described since the publication of Kraus's paper. But early in this work it became evident that the investigation of Paleozoic woods by Grand'Eury and Renault, and later by Morgenroth, Vater, and Felix, have made certain changes necessary in the genus Araucarioxylon as defined by Kraus. These investigations show very conclusively that it must be divided into two parts, and the later studies of Felix make it equally clear that the present state of our knowledge is sufficient to amply justify its division into three parts.

As the evidence which had led to the separation of Cordaites from Araucarioxylon is of considerable interest, it is presented somewhat in extenso.

\section{CORDAITES Unger.}

The name Cordaites was first employed by Unger in 1850.* It was founded principally upon the leaves, and Unger admitted but a single species $(C$. borassifolius), which had previousiy been described by Sternberg $\dagger(1820-25)$, first as Flabellaria borassifolia and later as Cycadites palmatus.t Sternberg, it will be observell, had regarded the first as a palm, the latter as a cycad.

The first to investigate the internal structure was Corda, $\S$ who in 1845 created the Flabellariaceæ for the species of Sternberg. $\mathrm{He}$ devoted a large plate to the elucidation of the internal structure, but as his specimens had not been well preserved he fell into error in his interpretation of the histological elements. He compared them in habit to Aletris and Draccena, but regarded the internal structure as similar to Lomatofloyos of the Lycopodiaceæ, and Unger, in his work above cited, placed Cordaites in the Lycopodiaceæ on this account.

In 1848 Germar || obtained a second species from Wettin in Germany, which he referred to Flabellaria observing that it was very closely allied to $F$. borassifolia of Sternberg. Unger, however, regarded it as a true palm, and retained it in the genus Flabellaria, although subsequent investigation has shown that Germar was correct in regarding it as allied to Cordaites. In the following year Brongniart published his celebrated "Tableau des generes de Végétaux fossiles, ๆ in which

\footnotetext{
* Gen. et sp. Plant. foss., p. 277.

+Versuch., I, fusc. 2, p. 27, Pl. Xvin ; fusc. 4, p. 34.

$\ddagger$ op. cit., I, fusc. 4, p. $32, \mathrm{Pl} . \mathrm{XL}$.

§ Beiträg. Fl. d. Vorweldt, p. 44, Pls. xxrv, xxv.

\| Verstein. d. Steinkohlgeb. Wettin u. Löbjun, p. 56, Pl. xxıI.

ๆ In Dictionnaire univ. d'Hist. Nat., Vol. XIII, pp. 113-115.
} 
he clearly for the first time dirined the true systematic relationships of these plants. He established the genus Pychnophyllum for Flabel. laria borassifolia of Sternberg and placed it with the genus Noggerathia, in the new family Nœggerathieæ, which he regarded as being related on the one hand to the Cycads and on the other to the Conifers. He placed it between these two families, and described at some length the form, nervation, and insertion of the leaves, but fell into the same error that Corda had in supposing that it was destitute of medullary rays.

There can be no doubt that this is the first correct reference of these plants to their true systematic position, and by the law of priority Brongniart's name, Pychnophyllum, should be the accepted one, and, indeed, Schimper* has reinstated it, but Unger's name, Cordiates, has obtained such wide acceptance, both in this country and Europe, that it is not within the scope of the present paper to insist upon changing it.

Göppert $\dagger$ was the next to take up the Nœggerathieæ, but he followed the older writers in relegating it to the Monocotyledons. His mention of Pychnophyllum was brief and unimportant, the main part being taken up with a description of the then known species of Noggerathia.

In 1855 Geinitz's work appeared on the carboniferous plants of Saxony. $\neq$ In this the Nœggerathieæ were again correctly referred to the Dicotyledons being placed next to the Cycads, and Unger's name Cordiates was restored in place of Pychnophyllum, which latter name had in some unaccountable manner begun to be quoted as 1852. This would of course give Cordaites priority, and is probably the reason it has been so generally accepted. Certain it is that from this time it has been, with the exception of Schimper, noted above, the accepted name, and there has also apparently been little or no question as to its dicotyledonous nature, although Ettingshausen, in a paper published in the same year (1855), placed it in the Lycopodiaceæ.

Geinitz reduced the following genera to Cordaites, or rather pointed out that they were the names that had been applied to the different parts of this plant: Fiabellaria ex. p. Sternberg, Rhabdotus Presl, Sternbergia Artis, Artisia Sternberg, Pychnophyllum Göppert 185:.ई He mentioned only two species viz: C. principalis German sp. and $C$. borassifolius Sternberg sp.

In his Dyas || Geinitz enumerated two additional species, while Göppert admitted but two from the Permian in his flora $\uparrow$ of that formation published in 1864-'65. In 1870-'72 Schimper,** as stated above, restored the name Pychnophyllum, but was at that time only able to enumerate four species. In the third volume of his Traité published in

* Traité Pal. Vég., Vol. II, p. 190.

† Foss Fl. d. Uebergansgeb. 1852, pp. 209-220.

‡ Verstein. d. Steinkohenfl. in Lochsen, p. 40.

ô Steinkohlfl, von Radnitz in Bohm.

|| Dyas oder d. Zechsteinform. u. d. Rothliegende, 1862, pp. 148, 149.

ศ Foss. Fl. d. Perm. Form., pp. 159, 160.

** Pal. Vég., Vol. II, pp. 190-192. 
1874, he however mentions * four or five additional species, that had been made known since the publication of the first notice, mostly by Dawson from the carboniferous of Canada and Nova Scotia. In the latter volume he speaks of the investigations that were just being undertaken by Brongniart on the silicified seeds of St. Etienne, and also of a verbal communication made to the Academy of Sciences by Grand 'Eury concerning the discovery of forests of Cordaites in the Loire basin.

The results of Grand'Eury's investigations were published in 1877 in his now justly celebrated "Mémoire sur la Flore carbonifère du Départment de la Loire." From this copious material, fortunately discovered in Central France, he was able for the first time to supply a complete history of Cordaites, including the leaves, branches, trunks, flowers, and seeds.

As the internal structure of the trunks and branches is the primary subject under discussion, our attention will hereafter be given entirely to this phase of the subject. The center of the trunk Grand'Eury found to be occupied by a very large pith, with which he was able to connect the heret ofore largely problematical organisms kuown as Artisia (Sternbergia Artis). Artisia, as generally known, consists of a struct. ureless cylinder, marked on the outside by numerous ridges or wrinkles, which as long ago as 1846 Dawes had suggested might be the cast of the medullars cavity of some plant possessing a pith similar to some living members of the Juglandaceæ, Euphorbiaceæ, etc. Dawson had also obtained specimens from the Carboniferous of Canada that pointed to the medullary origin of Artisia, but was in doubt as to the plants uniformly producing them, and from exceptionally well preserved specimens in England Williamson was able to establish the connection between Artisia and an undoubted Dadoxylon, but it was left for Grand'Eury to show its connection with Cordaites. According to him the larger trunks inclosed an Artisia pith having a diameter of from .05 to .08 or even $.10^{\mathrm{mm}}$, while in the branches it varied from .03 to $.01^{\mathrm{mm}}$.

Surrounding this pith was a dense woody zone, which was in its turn surrounded by a rery thick bark. This woody zone on its inner edge, when in contact with the pith, was composed of tracheïds which were provided with transverse striations and forming typical pseudo-scalariform tissue, gradually changing outwardly to true punctate tissue. These punctations were arranged in from one to four or five longitudinal rows, and when in more than one row becoming alternate and hexagonal by mutual pressure. These pits were perforated by an elliptical or circular pore, the form of the inner pore depending evidently somewhat upon age and also upon the state of preservation of the specimen. These punctations were confined to the radial walls of the cells, and, unlike some living Conifers, each cell was alwașs prorided with them. Percoursing between these tracheïds were numerous short medullary rays connecting the pith and bark. 
This description coincides, it will be observed, with the descriptions of species of Dadoxylon, particularly with what Williamson bas described as a typical Dadoxylon.* Indeed, there can be no doubt that some, at least, of the Paleozoic forms referred to Dadoxylon really represent the wood of Cordaites.

But the classic memoir of Renault, "Structure Comparée à quelques tiges de la Flore Uarbonifère," which appeared in 1879, must remain the most valuable contribution to our knowledge of the genus Cordaites. From a study of the very perfectly preserved specimens collected in the vicinity of Atun and St. Etienne, he was able to make out the cellular structure of the immense pith, of the medullary rays, of the wood cells showing the hexagonal aræolation, and also of the very thick bark. Likewise the structure of the leaves, the development of the male flower, manner of fertilization, and growth of the ovule were clearly described, so that we actually have a more complete knowledge of this long-since extinct genus than of many living genera. Renault proposes to place it as a distinct family between the Cycads and Conifers, being related, as Schenck has pointed out, by the male flowers to the Salisburiex, by the female flowers to the Cycads, while in the structure of the wood it can hardly be distinguished from the Conifers.

It being now acknowledged that there is a genus showing Araucarialike structure, yet unquestionably distinct from it, it becomes necessary to inquire if there are characters which can be used to distinguish them when there is not a sufficient amount of material to settle this macroscopically. According to Grand'Eury and Renault, and also by Morgenroth, Vater, and Felix, who have taken up the subject within a few years, there undoubtedly are characters that may be relied upon to separate Cordaites from the other Paleozoic woods. The possession of an Artisia pith is a clear indication that the example belongs to Cordaites, since, as stated above, Grand'Eury has always found the Artisia pith associated with Cordaites when the specimen has been entirely preserved. In all the species that have been described by Renault, Felix and others as typical, the punctations have entirely covered the radial walls of the tracheïds. There are several other minor characters that will be enumerated when we come to the detailed description of the species.

Having settled that Cordaites must be separated from the genus Araucarioxylon of Kraus, the further question arises as to what is to be done with the remaining forms. According to the best recent authorities, as Shenck, Felix, Lesquereux, Morgenroth, and Fontaine, the true Conifers of the Araucarian type do not extend into the Paleozoic. The Araucariæ first had their origin in the Jurassic, or in any case in the Mesozoic, and here the trunks are for the first time found associated with undoubted leaves and cones of the Araucarian type.

*Organization Foss. Pl. Coal-meas., vili, p. 222. 
The so-called Araucarites gracilis, described by Dawson from the Carboniferous and Permian of Canada, is without much doubt a species of Walchia, a well-known Permian genus.

As the Mesozoic and Tertiary forms are manifestly the only ones that can be justly referred to Araucaria, Felix has proposed * to confine the use of Araucarioxylon of Kraus to woods from these formations. This seems on the whole a desirable change and quite in harmony with modern views.

There now remain the Paleozoic forms not included in the genus Cordaites. As they can not of course be called either Cordaites or Araucarioxylon, Felix has proposed $\dagger$ to restore Endlicher's nameDadoxylon-for them. The term Dadoxylon, meaning simply ancient wood, is a very good one for these woods, inasmuch as it is non-committal, and the former may be changed from it at any time provided their true relatiouship may be made out. They are probably to be regarded as the ancestors of the true Araucariæ, although the discovery of more perfect material may possibly show them all to be related to or included in the Cordaiteæ.

CORDAITES † Unger.

\section{Cordaites Ouangondianus (Dn.) Göpp.}

Göppert in Nachträge z. Kenntniss d. coniferenhölzer d. Paleoz. Form., 1888, p. 9.

Dadoxylon Ouangondianum Dawson, Can. Nat., Vol, VI, 1861, p. 165, figs. (in text) 1-4.

Araucarioxylon Ouangondianum (Daws.) Kidston. Cat. Brit. Mus., 1886, p. 237.

Branching trunks with distinct zones of growth and a pith of Artisia (Sternbergia) type; wood cells very large, with three to five rows of contiguous alternate hexagonal areoles with oval pores; medullary rays with one to three series of cells and as many as fourteen rows of cells superimposed on each other (Dawson.)

Middle Erian (Devonian) formation, of Canada.

2. Cordaites Halli Dn. Sp.

Dadoxylon Halli Dawson. Quat. Jour. Geol. Soc. Lond., Vol. Xvir, 1862, p. 306, Pl. XIII, fig. 11 ; Foss. Pl. Devonian and Silurian Formations of Canada, 1871, p. 14, Pl. I, figs. 5, 6 .

Wood cells very large, with five rows of contiguous alternate hexagonal areoles; medullary rays very frequent, and with as many as thirty rows of cells superimposed. (Dawson.)

Hamilton group, Hemlock Creek, Ontario County, New York.

*Abhandl. d. k. geol., Landes-Anstalt, Bd. viI, 1886, p. 209. (Page 57 of reprint.)

† Op. cit., p. 209.

$\ddagger$ Felix and others write Cordä̈oxylon, but in view of what has been brought out in the preceding pages regarding the completeness of our knowledge of the life history of Cordaites, it does not seem expedient to use different generic names to designate simply different parts of the same plant. Göppert in his last work also adopted this view and wrote Cordaites for the species founded upon internal structure, as well as for those founded upon other parts of the plants. 
3. Cordaites Newberryi Dn. Sp.

Dadoxylon Neuberryi Dawson. Foss. Pl. Devonian and Upper Silurian Formations of Canada, 1871, p. 14, Pl. I, figs. 7-9; Newberry, Devonian plants from Ohio, Journ. Cincin. Soc. Nat. Hist., Vol. XII, 1889, p. 53, Pl. VI, figs. 3, $3 a, 3 b$.

Cells more slender than in the last species; areoles in two or three rows with large oblique pores ; medullary rays very numerous, of about eighteen rows of narrow cells in two series. (Dawson.)

Hamilton group, Ohio.

\section{Cordaites Clarkii Dn. Sp.}

Dadoxylon Clarkii Dawson. Foss. Pl. Erian (Devonian) and Upper Silurian Formation of Canada, 1882, p. 125.

Wood cells provided with two to three rows of slit-form bordered pores in hexagonal borders; medullary sheath of pseudo-scalariform and reticulated fibers; medullary rays numerous, short, and simple, with sometimes as few as four cells superimposed. (Dawson.)

Genesee shale, Canandaigua Lake, New York.

\section{Cordaites Brandlingii (Lindl. \& Hutt.) Göpp.}

Göppert Nachträge z. Kenntniss d. coniferenhölzer d. Paleoz. Form., 1888, p. 12, Pl. I, figs. 1-4.

Pinites Brandlingii Lindl. \& Hutt. Foss. Flora Great Britain, 1830, Vol. I, p. 1, Pl. I; Witham Entern. Struct., p. 73, Pl. Ix, figs. 1-6; x, figs. 1-6; XVI, fig. 3 .

Araucarites Brandlingii Göpp., in Bronn Gesch. d. Nat., Vol. III, p. 42.

Dadoxylon Brandlingii Endlicher, Synop. Conif., 1847, p. 299.

Araucarioxylon Brandlingii Kraus, in Schimp. Pal. Vèg., Vol. II, p. 382.

Cordaioxglon Brandlingii Felix, Sitzb. d. Natf. Gesell. Leipzig, 1882, Bd. Ix, p. 6.

Trunk branching, with large medulla; the concentric rings obsolete; tracheïds amply provided with bordered pits, which are in two to four, rarely one to five, contiguous, alternating series ; inner pores oblong; medullary rays in a single or rarely in two series of two to forty superimposed cells. (Göppert.)

Very widely distributed species, occurring at Wideopen, near Gosforth ; Hill Top, near Ushaw; Westgate, near New Castle; Newbeggin, Northumberland; Waldenburg, in Silesia; Saarbrücken; Central France, etc.

\section{Cordiates medullosus Göpp.}

Göppert in Nachträge z. Kenntness d. coniferenhölzer d. Paleoz. Form., 1888, p. 22 , Pl. I, fig. 11 ; II, figs. 12-24; III, figs. 25, 26.

Araucarites medullosus Göppert, Foss. Fl. d. perm. Form., 1864-'65, p. 259, Pl. LX, figs. 3-8.

Araucarioxylon medullosum Kraus, in Schimp. Pal. Veg., II, p. 383.

Trunks branching; medulla large, in the smaller branches of different ages the woody body becomes narrower, transversely septate; concentric circles obsolete; tracheïds pitted, the pits in one to two, rarely 
three to four rows, alternating, approximating or contiguous, small; medullary rass simple, usually of four to six, rarely one to eighteen, superimposed cells. (Göppert.)

Permian formation. Chemnitz.

\section{Cordaites intermedius Grand'Eury Sp.}

Dadoxylon intermedium Grand'Eury. Mém. sur la Fl. carbonif. d. Dep. la Loire, 1877 , p. 264.

Tracheïds provided with three or four series of hexagonal pits; medullary rays composed of two layers of superimposed cells. (Grand'Eury.)

This species is regarded by Grand'Eury as being intermediate be. tween C. Brandlingïi and C. Acadianum Dn. sp.

Carboniferous. Central France.

\section{Cordaites Stephanense Grand'Eury Sp.}

Dadoxylon Stephanense Grand 'Eury. Mém. sur la Fl. carbonif. d. Dep. la Loire, 1877 , p. 265.

Tracheïds small, provided with one or two rows of pores; medullary rays not abundant, short, composed of a single layer of from one to three small superimposed cells. (Grand'Eury.)

Carboniferous formation, Central France.

\section{Cordaites Subrhodeanum Grand'Eury Sp.}

Dadoxylon Subrhodeanum Grand'Eury Sp. Mém. sur la Fl. carbonif. d. Dep. la Loire, 1877, p. 266.

Tracheïds extremely small, provided with a single row of pores; medullary rays of from ten to thirty superimposed cells. (Grand'Eury.) Carboniferous formation, Central France.

\section{0 ? Cordaites Acadianum Dn. Sp.}

Dadoxylon Acadianum Dawson, Can. Nat. 1863, Vol. viII, p. 433. Quart. Jour. Geol. Soc. Lond., 1866, Vol. XxiI, p. 145, Pl. v, figs. 4-6.

Araucarioxylon Acadianum Kraus in Schimp. Pal. Vég., Vol, III, p. 577.

Large trees, usually silicified or calcified, with very wide wood cells, having three or more rows of small hexagonal areoles, each inclosing an oval pore; cells of the medullary rays one-third the breadth of wood cells, and consisting of twenty or more rows of superimposed cells in two series. Riugs of growth indistinct. (Dawson.)

Middle coal-measures, Joggins, Port Hood, Dorchester.

11. Cordaites materiarum Dn. Sp.

Dadoxylon materiarum Dawson, Can. Nat., 1863, Vol. viII, p. 433. Quart. Jour. Geol. Soc. Lond., 1866, Vol. xxir, p. 145, Pl. v, figs. 7-9.

Wood cells less wide than those of A. Acadianum, with two to rarely four rows of hexagonal pores. Medullary rays very numerous, with 
twenty or more rows of cells superimposed in one series. Rings of growth slightly marked. Approaches $C$. Brandlingii, but with the medullary rays much longer. (Dawson.)

Middle and upper coal-measures, Joggins, Malagash, Pictou, Glace Bay, Miramichi, etc.

\section{DADOXYLON Endlicher.}

Araucarites Presl. Araucarioxylon Kraus.

\section{Dadoxylon Beinertianum Endl.}

Endlicher, Syn. Conif., p. 300.

Araucarites Beinertianus Göppert, Foss. Fl. Schles. in Wimmer's Fl. v. Schles. ed. 2, Vol. II, p. 218; Monog. d. Foss. Conif., p. 233. Pl. XlII, figs. 1-3 ; XlıII, fig. 1. Araucarioxylon Beinertianum Kraus in Schimp. Pal. Vég., Vol. II, p. 381.

Annual rings evident; tracheïds broad, thin walled; pores in one to four series, approximate; medullary rays in a single series of from one to ten superimposed cells. (Göppert.)

Subcarboniferous formation, Falkenburg, in Silesia.

\section{Dadoxylon Tchichatcheffianum Endl.}

Endlicher, Syn. Conif., p. 300.

Araucarites Tchichatcheffianus Göppert in Tchichatcheff, Voyage dans l' Altai, p. 389 ; Monog. d. Foss. Conif., p. 235.

Concentric circles distinct, broad, equal; tracheïds with one to four series of hexagonal pores; medullary rays in a single series, similar. (Göppert.)

Subcarboniferous formation, Russia.

\section{Dadoxylon Buchianum Endl.}

Endlicher, Syn. Conif., p. 300.

Protopitys Buchiana Göppert, Monog. d. Foss. Conif., p. 229, Pl. xxxvir, figs. 4-7; Xxxvin, figs. 1,2 .

Araucarioxylon Buchianum Kraus, in Schimp. Pal. Vég., Vol. II, p. 381.

Concentric circles indistinct; tracheïds prosenchymatose, rather thick-walled; pores contiguous, compressed, in a single series, not observed on walls parallel to the medullary rays ; medullary rays simple, of a single row of superimposed cells. (Göppert.)

Subcarboniferous formation, Frankenberg, in Hesse.

\section{Dadoxylon Vogesiacum Ung.}

Unger in Köchlin-Schlumb. et Schimp., Terr. de trans. des Vosges, p. 342, Pl. $\mathrm{xxx}$, figs. A, 1-4.

Concentric circles apparent to the naked eye, nearly $1^{\mathrm{mm}}$ broad; medullary rays in transverse section appear numerous; tracheïds provided with one or two rows of pores which are contiguous and rounded when in a single series, irregularly hexagonal when in two series; medullary rays numerous, composed of a single layer of superimposed cells. (Unger.)

Grauwacke, of Niederburbach.

Proc. N. M. 89 39 


\section{Dadoxylon ambiguum Endl.}

Endlicher, Syn. Conif., p. 299.

Pinites ambiguus Witham Intern. Struct., p. 73, Pl. Ix, figs. 7, 8; x, figs. 7-9. Araucarites ambiguus Göpp. in T'chichatcheff Voyage dans l'Altai, p. 389.

Dadoxylon Unger in Köchlin-Schlumb. et Schimp., Terr. de trans. des Vosges, p. 343 , Pl. xxx, figs A, 1-4.

Concentric circles evident; the medullary rays in transverse section appear numerous and large ; tracheïds provided with two to three, or rarely four, rows of contiguous hexagonal pores; medullary rays composed of two or rarely three layers of superimposed cells. (Unger.)

Carboniferous formation, Gateshead, England, and Grauwacke, Niederburbach.

\section{Dadoxyion angustum Felix Sp.}

Araucarioxylon angustum Felix. Stud. über Foss. Hölzer. Inaug. Diss. Leipzig, 1882 , p. 81.

Annual rings plain ; tracheïds provided with one or two rows of small pores on the radial walls; medullary rays moderately high, composed of small narrow cells. (Felix.)

Carboniferous formation, Lake Illawarra, south of Sidney, New South Wales.

\section{Dadoxylon annulatum Dn.}

Dawson, Can. Nat., 1863, Vol. viII, p. 433 ; Quart. Jour. Geol. Soc. Lond., Vol. XXII, p. 146, Pl. v, figs. 10-13.

Wood cells with two or three rows of hexagonal disks; medullary rays of twenty or more cells superimposed, in two series; wood divided into distinet concentric circles, alternating with layers of structureless coal, representing cellular tissue or very dense wood. (Dawson.)

Middle coal-measures, Joggins.

\section{Dadoxylon antiquum Witham Sp.}

Pitus antiqua Witham, Intern. Struct., 1833, p. 71, Pls. III, IV, figs. 1-7; vII, figs. 9-12; viII, figs. $1-3$; xvi, figs. 9-10.

Pissadendron antiquum Unger, Chlor. Prot., p. 29 ; Göppert Monog. d. Foss. Conif., p. 2:30, Pl. xxxviII, figs. 3-6.

Concentric circles usually indistinct; tracheïds rather thick, the radial walls reticulated with two or three series of roundish areoles, which are separated from each other; medullary rays composite, consisting or four or five series of superimposed cells. (Göppert.)

Carboniferous formation, Lennel Braes and Tweed Mill, Berwickshire, England.

\section{Dadoxylon medullare Endl.}

Endlicher, Syn. Conif., p. 298.

Pinites medullaris Witham, Trans. Nat. Hist. Soc., Northumb., etc., Vol, I, p. 297 ; Pl. xxv, figs. 3-8; Intern. Struct., 1833, p. 72, Pl. vi, figs. 5-8; viI, figs. 7,8 .

Concentric circles obsolete; tracheïds provided with two to four series of contiguous areolæ; medullary rays of two to four series of superimposed cells. (Witham.) 
10. Dadoxylon antiquius Dn.

Dawson, Can. Nat., Vol. virI, 1863,p. 433 ; Quart. Jour. Geol. Soc. Lond., Vol. XXII, 1866, p. 146, Pl. v, figs. 1-3.

Wood cells narrow, thick-walled, provided with two to three rows of pores; medullary rays of three to four series of cells, with twenty or more superimposed, nearly as wide as the wood cells; rings of growth visible. (Dawson.)

Coal measures, Horton.

\section{Dadoxylon Schrollianum Göpp. Sp.}

Araucarites Schrollianus Göppert. Jahrb. d. Geol. Reichsanstalt. Wien, 1857, p. 7 ; Foss. Fl. d. Perm. Form., p. 248.

Concentric circles evident, one-quarter to two lines broad; tracheïds ample, moderately thin-walled, the pores in a single contiguous series; medullary rays small, in a single or rarely in two series of from one to fifty superimposed cells. (Göppert.)

Pẹrmian formation (Grès rouge), Bohemia, Silesia, Chemnitz in Saxony, Thuringia, etc.

\section{Dadoxylon stigmolithos Endl.}

Endlicher, Syn. Conif., p. 300.

Araucarites stigmolithos Göppert, in Index. Paleont., Vol. I, p .120; Foss. Fl. d. Perm. Form., p. 249; Göpp. in Mougeot, Essai d'une Fl. d. Nouv. Grès Rouge, p. 28, Pl. III, figs. 6,7 .

Concentric rings obsolete; tracheïds broad, thin-walled, provided with one to three series of small, strictly contiguous pores; medullary rays simple, of one to twenty superimposed cells. (Göppert.)

Permian formation, Bohemia, Saxony, and Frankreich of Val d'Ajol.

\section{Dadoxylon stellare Ung.}

Unger, Gen. et Spec. Pl. Foss., p. 380.

Araucarites stellaris Göppert, Foss. Fl. d. Perm. Form., p. 250.

The medulla large, stellate in outline; rings obsolete or 5 to $8^{\mathrm{mm}}$ broad; tracheïls equal, narrow, thick-walled, provided with a single row of small, contiguous pores; medullary rays simple, of two to thirty-three superimposed cells. (Unger.)

Permian formation, Chemnitz in Saxony.

\section{Dadoxylon Valdejolense Moug. Sp.}

Araucarites Valdejolensis Mougeot, Essai d'une Fl. d. Nour. Grès Rouge, p. 27, Pl. III, figs. 1-7 ; Göppert, Foss. Fl. d. Perm. Form., p. 250.

The medulla large, round (?) in outline; rings distinct; tracheïds equal, provided with two, rarely three, rows of small, contiguous pores; medullary rays numerous, simple, composed of one to twenty superimposed cells. (Göppert.)

Permian formation, Val d'Ajol. 


\section{Dadoxylon Rollei Ung.}

Unger, Der Versteint. Wald b. Cario, u. s. w., Sitzb. d. mathem-naturw. CI. d. Akad. zu Wien, Vol. xxxıII, 1858, p. 230, Pl. II, figs. 6-8.

Araucarites Rollei (Ung.) Göppert, Foss. Fl. d. Perm. Form., p. 250.

Concentric circles even, obscure; tracheïds ample in size, thickwalled, provided with two to three series of small, strictly contiguous pores; medullary rays simple or partly composed of two series of two to forty superimposed cells. (Unger.)

Permian formation, Erbstadt near Bönstadt in the Wetterau.

\section{Dadoxylon Richteri Ung.}

Unger, Der Versteint. Wald b. Cario, u. s. w., Sitzb. d. mathem-naturw. Cl., d. Akad. Vol. XxxmI, 1858, p. 230, Pl. II, figs. 9-11.

Araucarites Richteri (Ung.) Göppert, Foss. Fl. d. Perm. Form., p. 251.

Concentric circles even, obscure; tracheïds narrow, thick-walled, provided with one to two or three series of small subcontiguous pores; medullary rays simple, eomposed of one to eighteen superimposed cells. (Unger.)

Permian formation, Saalfeld in Thuringia.

17. Dadoxylon Saxonicum Geinitz Sp.

Araucarites Saxonicus Geinitz. Leit. pfl. d. Rothiieg., p. 25; Göppert, Foss. Fl. d. Perm. Form., p. 251, Pl. LIV; LV; LVI, figs. 2-4; LX, figs. 1, 2.

Concentric circles distinct; tracheïds large, provided with five series of spirally disposed, hexagonal pores ; medullary rays in a single series of five to thirty superimposed cells. (Göppert.)

Permian formation, Saxony.

18. Dadoxylon pachytichum Göpp. Sp.

Araucarites pachytichus Göppert. Foss. Fl. d. Perm. Form., 1864-'65, p. 257, Pl. LVII, figs. 6-9.

Concentric circles distinct; tracheïds with the walls so thick as to almost obliterate the lumen; walls provided with three to five series of hexagonally compressed pores; medullary rays composed of a single series of from five to twenty cells. (Göppert.)

Permian formation, Saxony.

\section{Dadoxylon Rhodeanum Göpp. Sp.}

Araucarites Rhodeanus Göppert in Wimmer. Fl. von Schlesien, Vol. II, p. 218; Monog. d. Foss. Conif., 1850, p. 235, Pl. Xlin, figs. 6-7 ; Foss. Fl. d. Perm. Form., 1864-'65, p. 256, Pl. Lvir, figs. 1-5.

Concentric circles evident; tracheïds moderately thick walled, provided with one to two series of contiguous pores; medullary rays simple, of one to many cells superimposed. (Göppert.)

Permian formation, Silesia. 
20. Dadoxylon Fleurotii Mougeot Sp.

Pinites Fleurotii Mougeot Essai d'une Flore du Nouv. grès rouge d. Vosges, 1851, p. 26, Pl. III, figs. 2-5.

Araucarites Fleurotii (Moug.) Göppert. Foss. Fl. d. Perm. Form., 1864-'65, p. 257.

Concentric circles distinct; tracheïds narrow, provided usually with a single row of contiguous angular pores, sometimes with two rows of alternating pores; medullary rays in a single series of from four to six superimposed cells.

\section{Dadoxylon Permicum Merckl. Sp.}

Araucarites Permicus Mercklin. Paleodendrol. Ross. 1856, p. 53, Pl. x, figs. 6-10; Göppert, Foss. Fl. d. Perm. Form., 1864-'65, p. 258.

Concentric circles broad, irregular, scarcely distinct; tracheids ample, usually six-sided, thin walled, provided with two to four, rarely five, series of contiguous, hexagonal pores, with minute inner pores; medullary rays equal, thick, many-pored, simple, composed of one to twenty, rarely forty, or more superimposed cells. (Mercklin.)

Permian formation, Russia.

\section{Dadoxylon cupreum Göpp. Sp.}

Araucarites cupreus Göppert. Monog. d. Foss. Conif., 1850, p. 233, Pl. XLIII, figs. 2-4 ; Foss. Fl. d. Perm. Form., 1864-'65, p. 258.

Concentric circles nearly obsolete; tracheïds ample, moderately thin walled, provided with one to two series of spirally arranged pores; medullary rays flexuous, composed of a single series of from one to ten large cells. (Göppert.)

Permian formation, Western Urals.

\section{Dadoxylon biarmicus Kutorga Sp.}

Peuce biarmica Kutorga, Verhandl. d. k. minerolog. Gesell., zu St. Petersburg, 1842, p. 9-11, Pl. II, figs. 4, $a, b, c, d$.

Araucarites Kutorga Mercklin. Paleodendrol. Ross, 1856, p. 56; Göppert, Foss. Fl. d. Perm. Form., 1864-'65, p. 258.

Concentric rings distinct; tracheïds large, six-sided, thin walled, provided with one, rarely two, series of small four to six angled pores; medullary rays in a single series of from four to ten superimposed cells. (Göppert.)

Permian formation, Gov. Perm, Russia. 


\section{Dadoxylon Aggyptiacum Ung.}

Unger, Der Versteint. Wald b. Cairo, u. s. w., Sitzb. d. Mathem-Naturw. Cl., 1858 , p. 228, Pl. I, figs. $3-5$.

Araucatites Agyptiacus (Ung.) Göppert. Foss. Fl. d. Perm. Form., 1864-65, p. 259.

Araucarioxylon Egyptiacum Kraus. See Schenk. Foss. Hölz. d. Liby. Wüste. in Palæontographica, vol. $\mathrm{xxx}, 1883$, p. 3, Pl. I, figs, 1, 2; II, figs. 3.

Concentric rings indistinct; tracheïds large, thick walled, provided with two to three series of small pores; medullary rays simple, formed of one to six superimposed cells. (Unger.)

Formation doubtful, possibly Cretaceous, near Cairo, Egypt.

\section{Dadoxylon Keuperianum Endl.}

Endlicher, Syn. Conif., p. 299. Araucarites Keperianus Göppert, Monog. d. Foss. Conif., p. 234.

Concentric rings obsolete; tracheïds rather narrow, thin walled, provided with one to two series of small, strictly contiguous pores; medullary rays simple or compound, of two to fifty superimposed cells in one or two series. (Göppert.)

Permian formation, Franconia and Würtemberg.

26. Dadoxylon Thuringiacum Born. Sp.

Araucarites Thuringiacus Borneman, Org. Reste. d. Lettenk. Thuring., 1856, p. 61, Pl. II, III, figs. 1-8.

Concentric rings indistinct; wood cells thick walled, narrow, lumen small; walls provided with one to two series of contiguous, round or slightly angular pores; medullary rays composed of a single series of from one to twelve superimposed cells.

\section{Araucarioxylon Arizonicum Knowlton.}

Proc. U. S. Nat. Mus., vol. XI, 1888, pp. 1-4, Pl. I.

Araucarites Möllhausianus? Göpp., in Möllhausen's Tagebuch einer Reise vom Mississippi nach den Küsten d. Siidsee. Leipzig, 1858, p. 492.

Annual ring not apparent to the naked eye, but under the microscope observed to be present, the yearly growth being separated by a laver of two to five tangentially compressed cells; tracheïds with moderately thick walls, which are provided on the radial sides with a single row of large contiguous pores or rarely with two rows of alternating pores, and on the tangential sides with numerous separated, perfectly round, small pores; medullary numerous composed of a single series of one to twenty. two short superimposed cells; resin ducts none. (Knowlton l. c.)

Habitat.-Triassic or lower Jurassic, near Fort Wingate, New Mexico; Lithodendron Creek and Chalcedony Park, Arizona. 
2. Araucarioxylon Edvardianum Dn. Sp.

Dadoxylon Edrardianum Dawson. Rept. on Geol. Struct and Mineral Resources of Prince Edward Island; Montreal, 1871, p. 45, Pl. III, figs. 25-27.

Trunks without distinct rings of growth, and with a central Pith not observed to have transverse laminæ. Wood cells with one, or rarely two, of contiguous hexagonal areoles. Medullary rays simple, infrequent, with two to ten rows of cells superimposed.

Habitat.-Triassic, Prince Edward Island.

\section{Araucarioxylon Wurtembergiacum Kraus.}

Schimp. Pal. Vég. II, p. 384.

Pinites Wïrtembergiacus Göppert. Monog. d. Foss. Conif., 1850, p. 212.

Concentric circles (nearly $10^{\mathrm{mm}}$ broad) indistinct; tracheïds equal, narrow, thick walled, provided with a single series of small contiguous pores; medullary numerous, composed of one to ten superimposed cells.

НАвітат.—Jurassic formation, near Würtemberg and Waidhofen.

\section{Araucarioxylon Virginianum Knowlton.}

Fossil Wood and Lignites of the Potomac Formation, Bull. U.S. Geological Survey, No. 56, p. 50, Pl. vir, figs. 1-4.

Annual ring very indistinct, about $2^{\mathrm{mm}}$ broad; tracheïds bearing one to two rows of hexagonal pits on the radial walls, mudullary rays simple; of one to twenty-seven superimposed cells; resin ducts none.

Навітат.-Potomac Formation, Taylorsville, Virginia.

5. Araucarioxylon Argilliacola Eichw. Sp.

Araucarites Argillicola Eichwald. Lethæa Rossica, Vol. II, 1865, p. 51, Pl. v, figs. 12-12c.

Concentric circle indistinct; tracheïds quadrate-ovate in section, small, thick-walled, provided with two, rarely three, series of angular pores; medullary rays provided with small pores.

Навітат.-Russia.

\section{Araucarioxylon Dœringii Conwentz.}

Sobre Algunos árboles Fosiles del Rio Negro. Boletin de la Acad. Nacional d. Cienc. en Cordoba, Vol. vir, 1885, p. 448.

Concentric circles distinct, broad, the exterior zone narrower; tracheïds provided with a single series of contiguous or with two series of aiteruate pores ; medullary rays composed sometimes of a single series of from one to sixteen superimposed cells, sometimes of two series of from five to forty cells.

Habitat. - Rio Negro, South America. (Suboligocene.) 


\section{Araucarioxylon Heerii Beust.}

Beust, Untersuch. ï. Foss. Hölzer aus Grönland. Neue Denkschriften d. allg. Schw. Gesellsch. f. d. gesammt-Naturwiss., Vol. xxIx, 1884, p. 16, Pl. I, II, III, fig. 9 .

Concentric circles less distinct, 2 to $3^{\mathrm{mm}}$ broad, both exterior and interior zones composed of thick-walled cells, which are rectangular, oval, or rarely hexagonal in transverse section; pores large, hexagonal, in one to two or rarely three contiguous series ; medullary rays numerous, simple or compound, composed of one to eighty-two superimposed cells, of which one, rarely two or very rarely three, come opposite to a single tracheïd; resin ducts none.

Навітат._Stanekerdluk, Greenland.

\section{Araucarioxylon Schmidianum Schleiden Sp.}

Felix, Studien ü. Foss. Hölzer. Inaug-Diss. Univ. Leipzig ; Leipzig, 1882, p. 62. Peuce Schmidiana Schleiden, ueber d. Nat. d. Kieselhölzer; Jena, 1855, p. 36.

Cedroxylon Schmidiana Kraus in Schimp., Pal. Vég., iı, p, 373.

Annual circles erident or sometimes indistinct; tracheïds provided with a single row of large contiguous pores; medullary rays two to fifty-five cells high, one to three cells broad.

Habitat.-Tiruvicary and Pattacary, near Pondicherry, India.

9. Araucarioxylon Robertianum Schenk.

Engler's Bot. Jahrb., Bd. III, 1882, p. 355.

Annual rings sharply separated by the presence of two or three layers of tangentially compressed tracheïds in the fall-wood; summerwood passing gradually into the fall-wood; walls of the tracheïds provided with one to four rows of spirally placed pores, which are irregularly compressed or hexagonal ; medullary rays numerous, in a single row or in the middle, rarely in two rows of cells, which range in number from one or two to twenty-four, or rarely as many as forty-two to forty.four.

HАвітат.—Assanole, near Ranigaudsch, India.

\section{Araucarioxylon latiporosum Kraus.}

Schimp. Pal. Vég., II, p. 384.

Pinites latiporosus Cramer in Heer's Flor. Foss. Arct., Vol. I, 1868, p. 176, Pl. Lx, figs. 1-8.

Annual rings distinct, 3.48 to $6.1^{\mathrm{mm}}$ broad; wood-cells 1.9 to $2.7^{\mathrm{mm}}$ long, 20 to 90.3 micro-millimeters thick, 46.6 to $80 \mu$ broad, provided with a single row of large contiguous pores, which have an outer average diameter of 35 by 17 micro-millimeters and an inner diameter of from 8.4 by 3 to 6 micro-millimeters; average number of pores to each wood-cell ten to thirteen, sometimes as many as forty; medullary rays composed of a single series of four to seventeen superimposed cells, the 
whole ray having a height of 76.5 to $379.9 \mu$; individual cells are 15.3 to $24.5 \mu$ (average of one hundred and ninety cells $20.64 \mu$ ) in diameter, 136 to $192 \mu$ (average $152 \mu$ ) long, and about $20 \mu$ broad ; the medullary rays are provided with numerous very large, roundish or elliptical pores, which have a breadth of 10 to $64 \mu$ and a height of 10 to $20 \mu$.

Навітат.-Green Harbor, Spitzbergen.

\section{Araucarioxylon Hügelianum Kraus.}

Schimp. Pal. Vég., II, p. 384.

Pinites Hïgelianus Göpp. in Bronn's Gesch. d. Nat., Vol. III, pt. 2, p. 40 ; Monog. d. Foss. Conif., 1850, p. 214.

Concentric circles $\left(2^{\mathrm{mm}}\right.$ broad) indistinct; tracheïds all thick walled; pores small, in a single contiguous series or separated; medullary rays numerous, simple, of two to twenty-four narrow superimposed cells.

Навітат.—Tasmania. "Formation probably oölitic." Schimper.

12. Araucarioxylon subtile (Merckl.) Kraus.

Schimp. Pal. Vég., II, p. 384.

Araucarites subtilis Mercklin in Paleodendrologicon ross., 1856, p. 54, Pl. XI.

Concentric circles distinct, 5 to $7^{\mathrm{mm}}$ broad; the cells thin walled; pores spirally disposed in two serles, contiguous, angled, small, or in a single series, being there subrectilinear, oval and remote; internal pore very small; medullary rays numerous, in a single series of one to fifteen superimposed cells.

Навітат.-Eastern Russia. (Siberia?)

\section{Araucarioxylon Möllhausianum Göpp. Sp.}

Araucarites Möllhausianus Göppert, in Möllhausen's Tagebuch einer Reise vom Mississippi nach den Küsten der Südsee. Leipzig, 1858, p. 492.

This species was not described by Göppert and consequently can not be identified. It is possibly the same as Araucarioxylon Arizonicum Knowlton (ante p. 614).

Hавітат,-New Mexico.

\section{DOUBTFUL SPECIES.}

\section{Dadoxylon Sternbergii Endl.}

Synops. Conif., p. 300. Araucarites Sternbergii Göppert, in Brown Gesch. d. Nat., III, 2, p. 41.

Araucarites Edwardianus Göpp.

See Beust Untersch. ü. foss Hölzer aus Grönland ; (Neue Denkschriften, Bd. xxıx, 1884) Ubersichts Tab. I.

U. S. National Museum, January, 1889. 


\section{$2 \mathrm{BHL}$ Biodiversity Heritage Library}

1890. "A revision of the genus Araucarioxylon of Kraus, with compiled descriptions and partial synonymy of the species." Proceedings of the United States National Museum 12(784), 601-617. https://doi.org/10.5479/si.00963801.12-784.601.

View This Item Online: $\underline{\text { https://www.biodiversitylibrary.org/item/53609 }}$

DOI: https://doi.org/10.5479/si.00963801.12-784.601

Permalink: https://www.biodiversitylibrary.org/partpdf/52729

\section{Holding Institution}

Smithsonian Libraries

\section{Sponsored by}

Smithsonian

\section{Copyright \& Reuse}

Copyright Status: Public domain. The BHL considers that this work is no longer under copyright protection.

This document was created from content at the Biodiversity Heritage Library, the world's largest open access digital library for biodiversity literature and archives. Visit BHL at https://www.biodiversitylibrary.org. 